\title{
Věda jako jednání: Pražský lingvistický kroužek, kulturní aktivismus a myšlení o divadle ${ }^{1}$
}

\author{
Martin Bernátek
}

Přínos Pražského lingvistického kroužku (dále jen „PLK“ nebo „Kroužek“) moderní lingvistice, literární vědě a estetice je obecně uznáván a dobře popsán. Toto sdružení může být také studováno jako příklad vztahů mezi vědeckým poznáním, kulturní tvorbou a modernitou. Jindřich Toman ve své monografii o PLK, příznačně nazvané „příběh jednoho moderního projektu“, popsal ustavení strukturálně-funkčního přístupu k jazyku a kultuře v souvislostech kosmopolitního prostředí meziválečné Prahy. Představil činnost ruských, ukrajinských a později německých emigrantů v Kroužku, úzké styky PLK s českou avantgardou, vztah k tehdejším projevům československé a evropské meziválečné modernity a rozpad PLK během stalinismu na počátku padesátých let.

V podobných výkladech často chybí přiblížení situace z konce třicátých let a první poloviny čtyřicátých let minulého století; Mnichovská dohoda a nacistická okupace většiny Evropy, stejně jako období druhé světové války „funguji““ jako symbolický předěl ve vyprávění mezi „klasickým obdobím“ Kroužku a jeho válečným „epilogem“ a (sebe)destrukcí po komunistickém puči v roce 1948. Pokud jde o estetiku, více než období války badatele a badatelky zřejmě přitahuje kulturní prostředí prvních dvou dekád Československé republiky („ČSR“), rozvoj avantgardního divadla a literatury a okolnosti vzniku základních textů a uskutečnění ikonických akcí PLK (1926-1936). Tímto zpo̊sobem může vzniknout oprávněná, ale nedostačující představa o přímé a příčinné souvislosti mezi avantgardním divadlem a „divadelní teorií pražské školy“.

Domnívám se, že se badatelky a badatelé dějin PLK zaměřují hlavně na vztah Kroužku k předválečné československé kultuře mimo jiné proto, že pracují s omezenými prameny. Tím nepřímo upozad'ují aktivity PLK v Protektorátu Čechy a Morava. Často citovaná Zpráva o činnosti Pražského linguistického kroužku za desítiletí jeho trváni 1926-1936 (Zpráva o činnosti Pražského linguistického kroužku za desítiletí jeho trváni 1926-1936 1936)

1 Studie vznikla v rámci řešení projektu „Český divadelní strukturalismus: souvislosti a potenciál“ (GAČR P409/11/1082).

2 K politické, nikoliv jazykové a etnické koncepci „československého národa“ viz (BROKLOVÁ 2003; RÁDL 2003). 
zahrnuje jen první dekádu PLK. Kronika Pražského linguistického kroužku (Kronika Pražského linguistického kroužku 1938), uložená v archivu PLK, končí v roce 1938 a dokumenty týkající se kroužku byly v rozsáhlé podobě publikovány teprve nedávno (ČERMÁK, POETA, ČERMÁK 2012; HAVRÁNKOVÁ a PETKEVIČ 2015).

I když se členové Kroužku příležitostně věnovali problémům divadla od druhé poloviny 30. let, právě až v období války se jimi zabývají cíleně. Členy sdružení se stávají Jindřich Honzl a Jiří Veltruský. Také další organizace se v této době více věnují divadelním tématům, navíc se k teoretickým i praktickým otázkám divadelní tvorby vyslovuje nová generace vědců a divadelníků. Během druhé světové války se česká kultura změnila, tvůrci začali definovat a vytvářet nový styl, který by proměnil avantgardní praxi dvacátých a třicátých let v něco nového a odlišného.

V následující studii se proto snažím ukázat, že tento kontext měnící se kultury je podstatný pro vznik strukturalistického přístupu k divadlu v Čechách. Místo hledání kontinuity mezi divadelní estetikou meziválečné avantgardy a čtyřicátými lety se zaměřím na souvislost způsobů (kolektivního) jednání PLK a toho, co lze v širokém slova smyslu považovat za „praxi“. Předem zdůrazňuji, že „praxi“ nepovažuji za protiklad „teorie“ či myšlení, které jsou ve všeobecném mínění rozdělovány přívlastky „konkrétní“ versus „abstraktní“. Naopak, myšlení a teorie jsou formou jednání; jsou praktikovány konkrétními aktéry v konkrétní historické a společenské situaci. Zaměřím se proto na kulturní souvislosti a diskuse, které utvářely zájem PLK o divadlo a které jednání Kroužku dále proměňovaly. Proto nejprve popíšu a upřesním materiální doklady existence Kroužku, jako jsou členství, přednášky a zasedání, publikační platformy a získávání finanční podpory. Vynechávání těchto materiálních a praktických prvků při studiu teoretických koncepcí totiž obvykle vede $\mathrm{k}$ jejich vnímání jako izolovaných textů bez historických souvislostí jejich vzniků.

\section{Členové PLK}

Když Kroužek v roce 1936 slavil první dekádu své existence, působilo v ČSR padesát jedna z celkem jednašedesáti členů ${ }^{3}$ (Zpráva o činnosti Pražského linguistického kroužku za desítileti jeho trváni 1926-1936 1936). To ovšem neznamená, že všichni byli Češi. Kroužek sdružoval akademické pracovníky Německé univerzity v Praze, emigranty ze sovětského Ruska (viz TOMAN 2011: 124-137), později uprchlíky z nacistického Německa (viz EHLERS 2003) a osobnosti dalších národností - ti spolutvořili kosmopolitní „republiku vědců“, jak nazval meziválečné Československo Jindřich Toman (TOMAN 2011: 152-153).

Československo spolu s Královstvím Srbů, Chorvatů a Slovinců totiž ve dvacátých letech minulého století pozvalo a podporovalo intelektuály, vědce a inženýry, kteří uprchli z Ruska po sovětské revoluci 1917. Představitelé ČSR při pomoci emigraci ze sovětské-

3 Přehled vztahů členů PLK k dalším československým lingvistům a jejich organizacím uvádí Tomáš Hoskovec, viz (HOSKOVEC 2010). 
ho Ruska, známé jako „Ruská pomocná akce“, předpokládali brzký pád bolševického režimu a zaměřili se na podporu studia a zaměstnání mladých. Proto ČSR vydržovalo instituce jako Ruskou lidovou (od 1933 svobodnou) univerzitu v Praze nebo Ruskou právnickou fakultu v Praze. Ruská pomocná akce vrcholila kolem roku 1926, poté klesala, až zanikla při proměně globální politické situace v polovině třicátých let a po podpisu Československo-sovětské smlouvy o vzájemné spolupráci v roce 1935 (viz BĚLOŠEVSKÁ 2000; GONĚC 1993; MACH 2012).

Společenské postavení ruských členů PLK není bez rozporů. Jeho dva klíčoví členové, Roman Jakobson a Petr Bogatyrev, přršli do Prahy jako členové sovětské diplomatické mise a byli během dvacátých let jejími zaměstnanci. Ve stejné době i později udržovali vztahy s dalšími významnými členy Kroužku, jako byl princ Nikolaj Trubeckoj, profesor slovanské filologie Vídeňské univerzity, emigrant pocházející z významné ruské aristokratické rodiny a klíčová osobnost ideologie eurasijství, nebo s další klíčovou osobností eurasijství, strukturálním geografem a emigrantem usazeným v Praze, Piotrem Savickým.

Rozmanitost členů PLK je ještě více patrná u německých vědců. K zakládajícím členům Kroužku patřil profesor srovnávací literatury na Německé univerzitě v Praze Friedrich Slotty; slavista a politický filosof Leopold Silberstein navázal vztahy s českým vědeckým prostředím už na slavistickém sjezdu v Praze v září 1929. Počet německých vědců v Kroužku vzrostl po nástupu NSDAP k moci v roce 1933, s následující emigrační vlnou a po celkovém zvýšení aktivit PLK v polovině třicátých let (EHLERS 2003: 54). V roce 1936 se členy Kroužku stali filosofové fenomenologické orientace (a často židovského původu) jako Oskar Kraus, Ludwig Landgrebe a Leopold Silberstein, o rok dříve estetik Emil Utitz, kteří se angažovali hlavně v Pražském filozofickém kroužku. Známým výsledkem spolupráce těchto dvou sdružení byla přednáška Edmunda Husserla uspořádaná 18. listopadu 1935 v PLK (SILBERSTEIN 1935a), po níž následovaly prosincové přednášky Krause (SILBERSTEIN 1935b) a Silbersteina (SILBERSTEIN 1935c). Politické změny ve střední Evropě $\mathrm{v}$ polovině tř̌icátých let minulého století rovněž vedly $\mathrm{k}$ vyhrocení vztahů mezi demokraticky a nacionalisticky orientovanými členy Německé univerzity v Praze. Jak poznamenal Klaas-Hinrich Ehlers, Kroužek nabízel inspirativní vědeckou debatu, jakou nově příchozí Němci mohli v nacionalistické a provinční atmosfére německé univerzity postrádat (EHLERS 2003: 62).

Přes zřejmý kosmopolitní ráz tohoto sdružení, v ČSR zdaleka ne obvyklý, převažovali mezi členy výrazně Češi. Ačkoliv je historie PLK vyprávěna hlavně prostřednictvím jeho nejvýznamnějších členů, Kroužek sdružoval osobnosti, které nebyly spojeny výhradně s akademickým prostředím, ani s výhradními stoupenci strukturální lingvistiky, jako např́klad ředitel pražského francouzského gymnázia Jean Arnaudiès nebo novinář a překladatel Pavel Eisner. Je třeba připomenout, že členská základna PLK, podobně jako převážná část tehdejší evropské vědy, ${ }^{4}$ byla silně maskulinní, jinými slovy šlo o kolektiv

4 Např. Časopis pro moderní filologii ve 30. letech výslovně považoval za spolupracovníky „pány přispěvatele“. 
vědců, ne vědkyň. Ty sice navštěvovaly přednášky, ale až na výjimky - jakými byly Julie Nováková, Marie Mayenowa a Giulia Porru - se účastnily jeho aktivit spíše v sociální roli manželek nebo posluchaček.

Přesto je intelektuální, tematická a geografická multiperspektivita vědeckého myšlení výjimečnou částí dědictví PLK. Z této pozice může být Kroužek pochopen jako sít spolupracujících aktérů působících v různých centrech Evropy (Oslo, Kodaň, Paříž, Ženeva, Bratislava, Vídeň, Bělehrad, Sofie atd.) a představen jako příklad nestátní, na spolupráci založené, veřejně angažované, často nonkonformní vědecké organizace, která jedná podle jasného programu v mezinárodním poli v opozici k tradicionalistickým vědeckým metodám a jejím národním omezením nebo až nacionalistickým motivacím (viz JAKOBSON 1929; TOMAN 2011: 143, 153).

\section{Setkání}

Přednáškové schůze Kroužku se konaly v pondělí obvykle v prostorách Filozofické fakulty Univerzity Karlovy a byly kromě členů PLK navštěvovány odbornou a kulturní veřejností. Pro významnější přednášky a zvláštní př́iležitosti byly voleny více reprezentativní až luxusní podniky jako hotel Zlatá husa na Václavském náměstí (O pražském linguistickém kroužku 1940) nebo Café Louvre. Výbor Kroužku nezasedal jen v univerzitních kabinetech, ale i v domácnostech svých členů (Zápis výborové schůze PLK konané 26. 5. 1936), v kavárnách a vinárnách, např́klad v podniku Dalmacija (Zápis výborové schuize PLK konané 6. 10. 1931; Zápis výborové schuize PLK konané 13. 10. 1931) či v Šuterově vinárně (Zápis výborové schůze PLK konané 28. 5. 1934). Někdy členové výboru spojili pracovní zasedání s narozeninovou oslavou (Zápis výborové schůze PLK konané 13. 10. 1931). Vilém Mathesius, který trpěl dlouhodobými zdravotními problémy a ve dvacátých letech byl už téměř slepý, organizoval ve svém pražském bytě setkání samostatné skupiny, zvané Kroužeček, která byla věnována převážně strukturálnímu rozboru angličtiny (Zápis výborové schůze PLK konané 30. 5. 1937). Podle Ondřeje Sládka navštěvovali členové PLK společně také divadelní představení (SLÁDEK 2014: 123). K tomuto neformálnímu posilování kolektivu patřilo rovněž publikování článků členů PLK o jiných členech sdružení. Vzájemné recenzování publikací bylo součástí kolegiality, i když někdy přešlo v ostrou kritiku (viz SLÁDEK 2014).

Příležitostně obohacovaly přednášky kroužku recitace; během Mukařovského přednášky o básnictví a jazykové kultuře 8. února 1932 pravděpodobně vystoupil Vítězslav Nezval (MÁGR 1932, Zápis výborové schůze 13. 10. 1931). Slavnostní zasedání Kroužku u př́iležitosti stého výročí narození Vítězslava Hálka (8. 4. 1935) zakončil herec Národního divadla Zdeněk Štěpánek recitací básníkových veršů (MÁGR 1935).

Někteří členové Kroužku udržovali od raných dvacátých let vztahy s umělci. Jakobson a Bogatyrev se setkávali s avantgardními tvůrci a levicovými intelektuály při společenských událostech v sídle sovětské diplomatické mise ve Vile Tereza (PIORECKÁ a PIORECKÝ 2014: 414). Tyto počáteční kontakty vedly např́iklad k Jakobsonově spolupráci 
s Devětsilem a avantgardními literáty (více viz ILLING 2001; TOMAN 2011: 238-260; WINNER 2015: 172-184) i k blízkému přátelství s Nezvalem nebo Vladislavem Vančurou (viz JAKOBSON 1997).

S Jakobsonem konzultoval svůj překlad poémy A. Bloka Dvanáct Jaroslav Seifert (text uvedl v roce 1921, krátce po vzniku českého překladu, J. Honzl v Dědrasboru), podobně s ním spolupracoval Josef Hora při práci na překladu Puškinova Evžena Oněgina (inscenačně jej zpracoval Emil František Burian v roce 1937 v Déčku).

Nezval, Vančura a další spisovatelé se o Kroužek začali zajímat především během debaty o jazykovém purismu a cyklu PLK „Spisovná čeština a jazyková kultura“ na začátku roku 1932 (TOMAN 1995: 162-165). Veřejný ohlas této úspěšné „bojové akce“ (TOMAN 2011: 185) proti pedantství šéfredaktora časopisu Naše řeč Jiřího Hallera vedl Kroužek k záměru uspořádat na podzim 1932 další cyklus přednášek s názvem Problémy básnické formy (Der 'Pražský linguistický kroužek' 1932: 8). Přednášky měly být věnovány Nezvalovi, Vančurovi nebo šlágrům Jiřího Voskovce a Jana Wericha. Jakobsonův odborný zájem o poetiku této herecké dvojice, známý hlavně z jeho Dopisu Jiřimu Voskovcovi a Janu Werichovi o noetice a sémantice švandy z roku 1937 (JAKOBSON 1937a), se proto zřejmě začíná projevovat nejpozději od roku 1932.

Tento cyklus se nakonec neuskutečnil v zamýšleném rozsahu, ani jeho průběh nebyl tak plynulý, jako tomu bylo v případě předchozího cyklu o jazykové kultuře; může být tedy pochopen spíš jako verbální manifestace zájmu o problémy současného umění než jeho aktuální uskutečnění. Roman Jakobson vydal pouze poznámky k zamýšlené přednášce, resp. - jak je uvedeno v názvu textu - k „monografii“ (JAKOBSON 1933), sám do programu cyklu nakonec přispěl až v květnu 1933 lingvisticky a historiograficky orientovanou přednáškou „O slovanských př́iklonkách“. Přitom ve stejnou dobu před Kroužkem upřednostnil atraktivnější prostředí; s přednáškou „Co je to poesie?“ (PIORECKÁ a PIORECKÝ 2014: 181) vystoupil v rámci mezinárodní výstavy Poesie 1932, která se konala v ř́jjnu a listopadu 1932 v Mánesu a představovala díla Salvadora Dalího, Maxe Ernsta, Paula Kleho, Toyen, Alberta Giacomettiho a dalších slavných umělců (WANIEKOVÁ 2014). Přednášky členů Kroužku nechyběly ani v přednáškovém cyklu o současném umění, který doprovázel První výstavu Surrealistické skupiny v ČSR, opět uspořádanou vlivným sdružením Mánes v lednu a únoru 1935 (Vier Vorträge über die zeitgenössische Kunst 1935). Jan Mukařovský či Roman Jakobson byli blízce spjatí s pražskými surrealisty (viz PETř́́ČEK 1996).

Jan Mukařovský přispěl do surrealistického máchovského vzdorosborníku Ani Labut' ani Lůna (NEZVAL 1935), který měl být opozicí vůči oficiální podobě oslav stého výročí Máchovy smrti. ${ }^{5}$ Mukařovský promluvil na vernisáži výstavy výtvarných prací Jindřicha Štyrského a Toyen v Praze 1938 a 1946, jejichž tvorbou se zabýval v několika článcích (MUKAǨOVSKÝ 1935a, 1938, 1946a, 1946b). Štyrský naopak přednášel v Mukařovského semináři na UK v zimě 1938 (BYDŽOVSKÁ 1996: 92). Roman Jakobson patřil k těm, kteří zahajovali brněnskou reprízu výstavy Štyrského a Toyen v tamní Galerii

5 PLK Máchovi věnoval opožděně vydaný sborník Torso a tajemství Máchova díla (MUKAŘOVSKÝ 1938). 
výtvarných umělců v dubnu 1938 (BYDŽOVSKÁ 1996: 93). Jiří Veltruský se účastnil diskusního večera o surrealistické ideologii ve velkém sále Slovanského ostrova, který byl připraven v rámci výstavy „Mezinárodní surrealismus“ v Topičově salónu na podzim 1947 (BYDŽOVSKÁ 1996: 305). Jindřich Honzl, který se stal členem Kroužku v roce 1940, patřil k zakladatelům Surrealistické skupiny v ČSR roce 1934 (a v lednu roku 1935 byl spolu s Vítězslavem Nezvalem, Emilem Františkem Burianem, Jaroslavem Ježkem, Konstantinem Bieblem a Závišem Kalandrou přijat do spolku Mánes) (BYDŽOVSKÁ 1996: 81). Spojení surrealistické a strukturalistické tradice, zejména v oblasti myšlení o divadle a filmu, bylo obnoveno v šedesátých letech 20. století v textech hlavního poválečného surrealisty Vratislava Effenbergera společně s celkovým obnovením zájmu o pražskou školu. Effenberger mimo jiné aktivity připravil monografii o Osvobozeném divadle, která bohužel nebyla dodnes publikována (EFFENBERGER 1974).

\section{Strany}

Je všeobecně známo, že čeští avantgardní tvůrci podporovali Komunistickou stranu Československa („KSČ““). Také surrealistická skupina v ČSR měla především z Nezvalovy iniciativy od začátku dobré vztahy s KSČ (a rozdílné postoje vưči stalinistickým čistkám vedly k rozkolu členů v roce 1938). Vztah Kroužku ke komunismu je převážně popsán právě prostřednictvím vztahů k avantgardě a také v souvislosti s obdobím oficiálního zavržení strukturalismu jeho členy a přizpůsobení se stalinistické vědecké doktríně po roce 1948. Méně je známo o předválečné podpoře levice členy PLK. Podpora levice a politiky SSSR se ale u některých jeho členů nelišila od postojů představitelů umělecké avantgardy (viz také VYKYPĚL 2013: 47-48).

Ačkoliv někteří členové Kroužku, jako například Jindřich Honzl nebo Bedřich Václavek, byli členy KSČ od dvacátých let 20. století, další členové PLK se výrazněji přiklonili k levici a k podpoře Sovětského svazu po roce 1935, poté, co zástupci podepsali ČSR a SSSR Smlouvu o vzájemné pomoci, která navazovala na stejnou francouzsko-sovětskou dohodu. V témže roce stanovila Kominterna politiku lidové protifašistické fronty, která umožňovala národním komunistickým stranám širší politickou a kulturní spolupráci. Například přehled redaktorů prvního čísla revue Praha-Moskva (viz tiráž Praha-Moskva 1936), jež vydávala Společnost pro hospodářské a kulturní styky s SSSR, zahrnuje jméno Bohuslava Havránka, druhé číslo pak uvede jméno předsedy PLK Viléma Mathesia. Bohumil Vykypěl upozorňuje na to, že Mathesiovo „romantické a idealistické“ pojetí SSSR a jeho sympatie k sovětskému Rusku, manifestované např. členstvím ve výše uvedené organizaci, odporují jeho koncepci praktického rozumu, které formuloval v Kulturnim aktivismu (VYKYPĚL 2012: 70-72).

Další členové Kroužku působící na Masarykově univerzitě, Vladimír Helfert a Frank Wollman, patřili ke členům výkonného výboru brněnské sekce Společnosti pro hospodářské a kulturní styky s SSSR, jejímž místopředsedou byl Bohuslav Havránek, který v roce 1935 podnikl cestu do SSSR (HAVRÁNKOVÁ 1990: 303). Jan Mukařovský v úno- 
ru 1935 přednášel na večeru sovětské literatury v Bratislavě o vztahu mezi sovětskou a československou literární vědou, setkání pořádala tamní pobočka Společnosti pro hospodářské a kulturní styky s SSSR (MUKAŘOVSKÝ 1935b).

Bohuslav Havránek, Frank Wollman, Arne Novák a František Trávníček podpořili výzvu Vyučování ruštině do středních škol! (1937) publikovanou v časopise Praha-Moskva. Do časopisu Země sovětů přispívali kromě Romana Jakobsona a Jindřicha Honzla také Karel Teige nebo Hubert Ripka, př́ležitostně i Edvard Beneš nebo Kamil Krofta. Jakobson během druhé světové války pracoval jako informátor zpravodajské služby londýnské exilové vlády, kterou měl na starosti zmíněný Hubert Ripka, který rovněž př́iležitostně přednášel v PLK (VÉVODA 1996: 71-73).

I když byl Kroužek československou policií považován za levicový (VÉVODA 1996: 70) a intervence do veřejné debaty patřila k jeho strategiím, nelze jej považovat za politicky vyhraněnou organizaci a pokud ano, pak spíše za zastánce provládních postojů. Přesto upozorňuji, že levicové sympatie, které v důsledku mají politický význam, existovaly již před druhou světovou válkou. Proto lze soudit, že spolupráce členů PLK s komunistickou stranou po roce 1945 a 1948 má hlubší souvislosti a nemůže být vnímána jen jako reakce na změněnou situaci po válce nebo jako pragmatické přizpůsobení se „novým poměrům“.

Jiný příklad politické a kulturní rozmanitosti v Kroužku dále představuje Jiří Veltruský. Vedle akademické kariéry patřil od čtyřicátých let minulého století k představitelům odborů a Československé sociálnědemokratické strany. Zatímco jeho starší kolegové z Kroužku jako Mukařovský (člen kandidátky KSČ ve volbách roku 1946 a rektor UK v letech 1948-1954) a Havránek (děkan FF UK v letech 1948-1951) pomáhali po roce 1948 etablovat nový lidově demokratický totalitární režim a přizpo̊sobili se dogmatické vědecké a politické praxi, Veltruský, po roce 1945 člen sociální demokracie, záhy po únoru 1948 emigroval se stranickým kolegou Arnem Haisem do Paříže, kde pokračoval v politické aktivitě jako člen výboru zemské organizace strany ve Francii, publikoval texty o stalinistickém teroru a pracoval v mezinárodním dělnickém hnutí (HOSKOVEC 2012: 206-229, Veltruský 2010, LUŽA 2001: 23, 56).

Na druhou stranu, členové PLK Vilém Mathesius, Jan Mukařovský a Otokar Fischer patřili k rozmanitému sdružení Pátečníků (KUDLÁČKOVÁ 2001: 51; POJAR 2001: 59), kteří jako skupina reprezentovali liberálně demokratickou inteligenci a podporovali politiku „Hradu“ a T. G. Masaryka. Kroužek vyjádřil úctu Masarykovi slavnostním zasedáním u př́ležitosti prezidentových 80. narozenin v březnu 1930 a sborníkem Masaryk $a \check{r} e c ̌$ (1931). ${ }^{6}$ Toto gesto čerstvě oficiálně institucionalizované vědecké skupiny mohlo mít význam i pro její veřejné přijetí.

Dobrého spojení s vysokými představiteli státu využili členové PLK Emil Utitz a Otokar Fischer, když intervenovali u tehdejšího ministra zahraničí, historika a redaktora Prager Rundschau Kamila Krofty pro založení Lektorátu Československé řeči a civilisace v Tartu, který měl zastávat Leopold Silberstein. Tento přispěvatel Prager Rundschau

6 Více ke vztahu PLK k Masarykovi (TOMAN 2011: 104-106, 119-123). 
a propagátor politické koncepce Masaryka a Beneše zde začal působit na podzim 1937. Jmenování Němce, Žida a emigranta na místo lektora české kultury ovšem pobouřilo dobový český xenofobní tisk (HERRMANN 2015: 186).

\section{Platformy a finanční prostředky}

Zatímco sborníky jako Masaryk a řč nebo Čteni o jazyce a poesii (HAVRÁNEK a MUKAŘOVSKÝ 1942), ${ }^{7}$ kde vyšla Veltruského studie „Drama jako básnické dílo“, byly vydávány příležitostně, edice Travaux du Cercle Linguistique de Prague sloužila k šírení vědeckých článků a publikací v zahraničí, časopis Slovo a slovesnost byl pravidelným (čtvrtletním) prostředkem propojování jazykovědy, literární vědy a ostatních oborů s československým kulturním životem.

Členové se podíleli na velkých encyklopedických projektech jako Československá vlastivěda (1929-1936), Masarykưv slovnik naučný (1925-1933), Slovenský naučný slovnik (1932) a Ottův slovnik naučný nové doby (1930-1943) (podrobněji viz HOSKOVEC 2010), připravovali rovněž učebnice a věnovali se praktickým otázkám jazykového vzdělávání (viz též VYKYPĚL 2009: 49).

Bohuslav Havránek se během celé své vědecké kariéry zabýval didaktikou a jazykovou výchovou, s kolektivem autorů vypracoval Cvičebnici jazyka českého pro I.-IV. tř́du střednich škol (1933-1936), Stručnou mluvnici českou pro středni školy (1950) a další učebnice (viz ŠMEJKALOVÁ 2013). Bohumil Trnka se otázce středního školství a výuky angličtiny věnoval v několika článcích a spolu s dalšími redaktory připravil Učebnici anglického jazyka pro středni školy (1926-1928), která se do roku 1948 dočkala tří vydání. Autorem učebnic byl také Alexand Isačenko. Členové PLK Zdeněk Vančura, Leontij Kopeckij a Jan Čada se dlouhodobě věnovali praktickému uplatnění strukturalistické jazykovědné metody v oblasti hospodářské lingvistiky (viz PATELKA 1972). Během války Kroužek zamýšlel vydávat jazykové učebnice, doprovázené gramofonovými záznamy, dále slovníky a praktické mluvnické příručky (Návrh smlouvy o spolupráci mezi Pražským lingvistickým kroužkem a nakladatelstvím Melantrich. 28. 4. 1944).

Vedle přednášení a publikování článků vystupovali Mukařovský, Jakobson, Mathesius a další se svými příspěvky v Československém rozhlase (SLÁDEK 2014: 131). PLK se rovněž pokoušel o oficiální spolupráci s Československým rozhlasem v oblasti výzkumu spisovného jazyka, ale jednání se protahovala a k realizaci pravidelného pořadu nedošlo (Korespondence PLK s Jaroslavem Kosem).

Mathesius veřejně formuloval své názory na různé dobové otázky jako československá kulturní orientace, reforma české vědy nebo vztah k tradici. Jeho pojetí vědy, a tedy i Kroužku patřilo do širší představy „kulturního aktivismu“ a aktivistického přístupu ke společným problémům vzdělanosti, společnosti a kultury obecně (viz MA-

7 Čteni o jazyce a poesii mělo být prvním svazkem nové edice, viz tiráž (HAVRÁNEK a MUKAŘOVSKÝ 1942). 
THESIUS 1925, 1945). Proto mohou být aktivity Kroužku oceněny také v oblasti popularizace vědy. Propojování vědeckého myšlení s veřejným životem zůstává významnou části jeho dědictví. Praxe PLK inspirovala vznik několika dalších sdružení.

Ještě před institucionalizací PLK vznikl na podzim 1929 v Praze Etnografický kroužek, jehož cílem bylo rozvíjet moderní etnografické a etnologické metody a pořádat diskuse a přednášky. Na prvním večeru byli vedle Petra Bogatyreva Roman Jakobson, Petr Savickij, Edmund Schneeweis, Dmytro Čyževskyj, Gerhard Gesemann, Karel Plicka, Václav Fabián a Drahomíra Stránská. Bogatyrev představil program Kroužku, projednány byly otázky hranic etnografie a etnologie, vztahy mezi etnografií, jazykovědou, geografií, dějinami a filosofií, stejně jako otázka vztahu tzv. vysokých a primitivních kultur (Ein „Ethnographischer Zirkel“ 1930; EHLERS 2011: 26-28).

Slavista Gerhard Gesemann založil na Německé univerzitě v Praze v dubnu 1930 Jihoslovanský kroužek (Südslavischer Zirkel), jehož valná hromada se uskutečnila v červnu téhož roku. Gesemann, resp. Jihoslovanský kroužek, měl pořádat pravidelná pracovní setkání, diskuse a otevřené přednáškové večery a svou práci organizovat dle semestrálních témat (prvním byl Ljubomir. P. Nenadović) a dvakrát až třikrát za semestr připravit otevřené přednáškové večery. Jako první v Jihoslovanském kroužku přednášel muzikolog Německé univerzity v Praze a člen PLK Gustav Becking. Členové kroužku podnikli pětitýdenní exkurzi podél chorvatského pobřeží, financovanou Ministerstvem školství a národní osvěty a Kanceláří prezidenta republiky (Südslavischer Zirkel der Slavisten an der Deutschen Universität in Prag, dále viz (GESEMANN 1933). Další osudy tohoto sdružení jsou mi neznámé, pravděpodobně byl Gesemannem dále organizován jako pracovní skupina pro (jihoslovanskou) lidovou epiku v rámci Německé společnosti pro slovanský výzkum (Deutche Gesellschaft für slavistische Vorschung) (GESEMANN 1933: 143-144), kterou Gesemann založil spolu se slavistou a aktivistickým německým politikem Franzem Spinou v roce 1930 po vzoru PLK a Moskevského lingvistického kroužku (GESEMANN 1930; EHLERS 1997: 176). Tato společnost byla zodpovědná za vydávání odborných revue Germanoslavica a Slavische Rundschau, které byly koncipovány jako platformy spolupráce českých germanistů a německých slavistů, kde publikovala řada členů PLK.

Po vzoru PLK založili v roce 1932 Leopold Silberstein s Klausem Mehnertem na Berlínské univerzitě Slavistický kroužek. Toto pracovní sdružení se mělo zabývat různými oblastmi - od lingvistiky přes literární a duchovní vědy a umění až po politické dějiny, geografii a hospodářství. Na programu v letním semestru 1932 byla témata problematiky slovanských národností, slovanského romantična a ruského středověku (EHLERS 2005: 488; Slavistische Arbeitsgemeinschaft in Berlin 1932). PLK také inspiroval vznik Kodaňského lingvistického kroužku.

Ambiciózní, a proto nákladná činnost Kroužku nemohla být hrazena pouze z prodeje publikací nebo z členských příspěvků, jejichž výběr nebyl ideální. ${ }^{8}$ Aktivity PLK se proto neobešly bez podpory státu. Československá vláda a prezident podporovali Kroužek od

8 Př́íspěvky neplatili hlavně zahraniční členové, kteří navíc dostávali publikace PLK zdarma (Viz Zápis výborové schưze PLK konané 1. 2. 1938; 19. 12. 1938; před 27. 2. 1939). 
doby jeho oficiálního vzniku v roce 1930. Ministerstvo školství a národní osvěty (MŠANO), Ministerstvo zahraničních věcí (MZV) a Kancelář prezidenta republiky poskytovaly během třicátých let PLK subvence na pokrytí nákladů na publikace a zahraniční vztahy, respektive na propagaci československé vědy v zahraničí. Zatímco subvence na publikace, hlavně na edici Travaux, byly výrazné na začátku třicátých let a souvisely s intenzivními publikačními aktivitami Kroužku, podpora zahraničních styků vzrostla a převýšila příspěvky na publikace v druhé polovině dekády.

V roce 1931 PLK získal 6000 Kčs od MŠANO na pokrytí nákladů za vydání prvních dvou svazků Travaux a 15000 Kčs na publikační činnost. Další 2000 Kčs získal PLK od prezidentské kanceláře na vydání IV. Svazku Travaux (Zápis výborové schůze PLK konané 28. ledna 1931; Dopis Ministerstva školstvi a národni osvěty z 9. 10. 1931). Cena tisku prvních dvou svazků ovšem dosáhla 23000 Kčs (Dopis ministerstva školství a národni osvěty z 5. 2. 1930). Celkové náklady PLK na tisk do konce roku 1935 činily 52232 Kčs (Zpráva o činnosti Pražského linguistického kroužku za desítiletí jeho trváni 1926-1936 1936: 13). Zatímco první čtyři svazky Travaux vyšly relativně záhy za sebou (1929, 1929, 1930, 1931), další již vycházely v delších intervalech (1934, 1936, 1939, 1939).

Do konce roku 1935 Kroužek subvencemi nebo dary získal celkem 50650 Kčs (Zpráva o činnosti Pražského linguistického kroužku za desítiletí jeho trváni 1926-1936 1936: 13). V roce 1936 získal například od MŠANO 7000 Kčs na zahraniční kontakty, 5000 Kč od MZV na propagaci československé vědy a 5000 Kč od prezidentské kanceláře na pokrytí účasti na IV. mezinárodním jazykovědném sjezdu v Kodani (Dopis Ministerstva školstvi a národni osvěty z 21. 3. 1936). Pro srovnání, Jakobsonův roční plat na Masarykově univerzitě v roce 1934 činil 36000 Kčs (JAKOBSON 1997: 106, 112-113) a obraz od Salvatora Dalího z výstavy Poesie 1932 v pražském Mánesu mohl být koupen za 9000 Kčs (a to nepatřil k nejdražším položkám katalogu) (viz WANIEKOVÁ 2014: 226).

Průsečíkem těchto aktivit se zřejmě mohl stát projekt mezinárodního vědeckého časopisu Acta linguistica: Revue internationale de linguistique structurale, který měl redigovat Kodaňský lingvistický kroužek společně s PLK (Acta linguistica 1938). Revue Acta linguistica měla nahradit edici Travaux, která se tím měla změnit na periodikum (Zápis výborové schůze PLK konané 1. 2. 1938). Členové vedení PLK Mathesius a Mukařovský o podpoře mezinárodní revue vyjednávali v březnu 1938 přímo s prezidentem Edvardem Benešem. Jak výbor PLK konstatoval, audience měla „uspokojivý průběh“ a skončila př́ślibem relativně vysoké podpory (Zápis výborové schůze PLK konané 21. 3. 1938). Acta linguistica začala vycházet bez aktivní účasti PLK, ale alespoň se symbolickým uvedením Jakobsonova jména (HOSKOVEC 2010).

Vedle finančních příspěvků podporoval československý stát sdružení i nepřímo. MŠANO a MZV rozesílaly na své náklady publikace členů Kroužku zahraničním vědcům (Dopis Ministerstva zahraničnich věci Československé republiky Vilému Mathesiovi z 25. 10. 1929; Dopis PLK Ministerstvu školstvi a národni osvěty z 20. 9. 1934), Ministerstvo školství př́iležitostně kupovalo knihy vydané PLK. Kroužek rovněž hledal další veřejné, soukromé a zahraniční zdroje, často přitom využíval článků publikovaných o svých akti- 
vitách v deníku Prager Presse, aby doložil závažnost svých činností (viz Dopis Rockefellerovy nadace B. Trnkovi z 25. 10. 1932).

V roce 1937 MŠANO předplatilo dvacet výtisků Slova a slovesnosti pro střední školy (Zápis výborové schioze PLK konané 21. 12: 1937). Josef Hrabák, resp. PLK získal v lednu 1941 od Národní rady badatelské 5000 Kčs na vydání knihy Smilova škola a Vladimír Skalička 2000 Kčs na vydání publikace $O$ vývoji české deklinace (Dopis Národni rady badatelské Josefu Hrabákovi z 27. 1. 1941; Dopis Národni rady badatelské Josefu Hrabákovi z 15. 1. 1941, 1941). Kroužek podporovalo i hlavní město Praha, Slovanský ústav a Francouzský institut Ernsta Denise (Zpráva o činnosti Pražského linguistického kroužku za desítiletí jeho truáni 1926-1936 1936: 13). Roman Jakobson v roce 1936 vyjednával se zástupci firmy Bała podporu vydání slovníku o hospodářské lingvistice, který by redigovali členové PLK Josef Čada a Leontij Kopeckij. Tento plán se ale neuskutečnil (Zápis výborové schưze PLK konané 27. 1. 1936; Zápis výborové schioze PLK konané 9. 3. 1936; Zápis výborové schuize PLK konané 7. 4. 1936; Zápis výborové schuize PLK konané 26. 5. 1936 1936). PLK podobně neuspěl s žádostí o podporu Rockefellerovy nadace v roce 1932 (Dopis Rockefellerovy nadace B. Trnkovi z 25. 10. 1932).

\section{Přiblížit se: divadelní avantgarda a PLK}

Sborník Masaryk a řě̌, stejně jako Slovo a slovesnost a další publikace reprezentovaly Kroužek na Výstavě československé avantgardy, kterou organizovalo Divadlo D 37 v květnu 1937. Výstavu připravoval režisér Emil František Burian se svým scénografem Miroslavem Kouřilem, Karlem Teigem a architektem Janem Vaňkem. Představeny zde byly aktuální ukázky z výtvarného umění, divadla, literatury nebo soudobé vážné hudby. Členové PLK Jan Mukařovský, Roman Jakobson, Vladimír Helfert nebo Pavel Eisner byli součástí čestné komise výstavy (D 37: 1937).

Mezi členy čestné komise dále patřili náměstek Ministra školství a národní osvěty a divadelní kritik Jindřich Vodák a ředitel Národního divadla Stanislav Mojžǐš-Lom. Z této sestavy osobností je patrné, jak úzce byla československá avantgarda ve třicátých letech spjata s ideou Československé republiky a jak otevřené bylo chápání avantgardnosti (BERGMANOVÁ 1937a). Kulturní praxe Kroužku jako kolektivní akce, veřejná angažovanost i spolupráce se soudobými umělci jistě korespondovala s aktivismem avantgardních tvůrců, kteří od poloviny třicátých let usilovali o širši veřejné uznání a čím dál více o spolupráci v odporu proti fašismu. Podle Květoslava Chvatíka „málokdy přivítali umělci tak spontánně určitou ryze odbornou, značně speciálně vědeckou estetickou teorii“ (CHVATÍK 1968: 87). Nebyla to ovšem pouze teorie, ale také praxe, způsob společenského jednání, které tuto teorii formovalo, používalo a obklopovalo. Je jisté, že Divadlo D inspirovalo členy PLK ke studiu divadla, stejně dobře může být ale vnímáno i jako jedna z jeho platforem.

Mukařovský a Bogatyrev se účastnili mezinárodní konference, která výstavu doprovázela. Právě zde Mukařovský přednesl svou přednášku „O jevištní řeči v avantgardním 
divadle“ a další kratší text o jevištním dialogu uveřejnil několik týdnů před konferencí v časopise Program D (MUKǍ̌OVSKÝ 1937a). Bogatyrev pravděpodobně na konferenci mluvil o lidovém divadle a jeho významu pro moderní divadelnictví (BERGMANOVÁ 1937a) a Emil František Burian s herečkou Ninou Jirsíkovou o funkci moderního tance na divadle (BERGMANOVÁ 1937b). Bogatyrev krátce před konferencí publikoval v Programu $D$ dva články o lidovém divadle (BOGATYREV 1937a, 1937b) a později také o divadle a folkloru, př́ležitostně zde publikovali Roman Jakobson (JAKOBSON 1937b), Vilém Mathesius (MATHESIUS 1940), František Trávníček (1940) a germanista Vojtěch Jirát (JIRÁT 1939, 1940). Účastníci konference diskutovali o možnosti založení mezinárodního časopisu o avantgardním divadle a zdůrazňovali nutnost mezinárodní spolupráce avantgardních divadelníků. Spoluorganizátorka konference Marie Bergmanová ocenila, že „na pražské konferenci [byla] poprvé uskutečněná spolupráce s badateli lidového divadla a moderní lingvistiky“ (BERGMANOVÁ 1937a). Avantgardní divadelníci z Déčka při svém hledání mezinárodní spolupráce a uznání uvažovali podobně jako PLK v případě výše zmíněného časopisu Acta linguistica.

Spolupráce mezi Kroužkem a Divadlem D měla spíše praktické aspekty. Mukařovský už v červnu 1936 svým proslovem zahájil premiéru Burianovy inscenace Máj (Plakát Máj, 1936) a pravděpodobně přednášel před premiérou hry F. X. Šaldy Ditě v Divadle $\mathrm{D}$ v roce 1937. Mukařovský a Burian tím uctili památku nedávno zesnulé osobnosti české kultury a také člena PLK, F. X. Šaldy. Mukařovského proslov se patrně stal základem jeho studie „Šaldova dramatičnost“ (MUKǍ̌OVSKÝ 1937c). Burian přispěl v roce 1939 do Slova a slovesnosti článkem o problémech jevištní řeči, kde se vyslovoval pro její vědecké hodnocení a kodifikaci (BURIAN 1939: 32).

Vzájemná náklonnost získala sofistikovanější organizační podobu na konci třicátých let, kdy vzniklo sdružení na podporu Burianova divadla - příznačně nazvané Kruh přátel D 40 (NOVÁK 1940). K jeho zakladatelům patřili Petr Bogatyrev a překladatel Bohumil Mathesius, bratranec Viléma Mathesia. Součástí jeho výboru byl člen PLK Antonín Hartl (Kruh přátel D 40, 1940). Klub svoji činnost zahájil na začátku roku 1939. Zřizoval pobočky v dalších městech, organizoval zájezdy do Prahy a pořádal přednášky a besedy o moderním umění (NOVÁK 1965: 45-46). Pro své členy uspořádal „Kurs přednášek o divadelní výchově obecenstva“. Právě zde přednesl Mukařovský svůj dnes kanonický text „K dnešnímu stavu teorie divadla“, který později publikoval v Programu D 41 (MUKAǨOVSKÝ 1941) a ve kterém mj. odkazoval na Honzlův text o „Hereckém paradoxu“ Denise Diderota, otištěném rovněž v Programu D (HONZL 1940a). Proto je tato studie příkladem nejen moderního myšlení o divadle, ale i důkazem úzkého vztahu moderní vědy, umělecké praxe a její popularizace.

Oboustranný zájem a výslednou spolupráci divadelníků a členů PLK ve stejné době provázelo více soustředných aktivit. Ze studia archivních dokumentů je patrné, že vedení PLK se začalo výrazněji zajímat o divadelní tvorbu od roku 1935.

Divadelní režiséři Jiří Frejka, Jindřich Honzl, Emil František Burian a dramatik Frank Tetauer měli být pozváni na přednášku Františka Trávníčka v PLK o správné české výslovnosti v květnu 1935 (Zápis výborové schưze PLK konané 29. 4. 1935). Podle 
archivních pramenů diskutovali členové kroužku o spolupráci se jmenovanými režiséry a rozhlasovým dramaturgem Václavem Růtem ${ }^{9}$ v červnu 1935. Proto považuji Trávníčkovu přednášku, v níž se zabýval jevištní řečí a výslovností ve filmu a rozhlase, za první soustavné pojednání o divadelním tématu v rámci Kroužku (nn 1935). Jakobson zároveň pomáhal dalšímu členovi PLK Otokaru Fischerovi s překladem Puškinova Borise Godunova, který byl inscenován v Národním divadle Jiřím Frejkou k uctění stoletého výročí Puškinova úmrtí. Kroužek k „Puškinovu roku“ 1937 přispěl speciálním číslem Slova a slovesnosti, které obsahovalo Frejkovu reflexi jeho inscenace Borise Godunova (FREJKA 1937).

V roce 1937 vznikla v rámci ortoepické komise PLK skupina pro studium zvukové stránky jevištní řeči, jež požádala o spolupráci divadelní tvůrce. Zájem Kroužku o divadlo se ale netýkal jen jazykovědných otázek. Myslím si, že vycházel z potřeby kontaktu se současným uměním. Mukařovský dokládal vznikem této skupiny potřebu konkrétní spolupráce mezi vědou a uměním, jelikož „estetika potřebuje styku s uměním živým, protože jako východiska má zapotřebí vnímání bez přehrad“ (MUKAŘOVSKÝ 1937b).

Ondřej Sládek zdůrazňuje, že jádro Mukařovského textů o divadle - se zaměřením na dialog, monolog a jevištní řeč - vznikalo od poloviny třicátých let do roku 1948 (SLÁDEK 2014: 133). Zejména v druhé polovině třicátých let koresponduje Mukařovského zájem o divadlo s jeho univerzitními přednáškami a s užší spoluprací PLK s divadelníky.

Ve třicátých letech pořádal Jan Mukařovský několik kursů a seminářů o estetice divadla a filmu na univerzitách v Bratislavě a v Praze (SLÁDEK 2014: 133). Se svými studenty na Univerzitě Karlově navštěvoval divadelní zkoušky, pozval sem např́iklad Jindřicha Štyrského (BYDŽOVSKÁ 1996: 93). Tento kurs navštěvoval mimo jiné Karel Brušák, ostatně první verze jeho textu „Znaky na čínské divadle“ původně vznikla jako referát pro Mukařovského seminár. ${ }^{10}$ Tento projekt byl přerušen okupací ČSR nacistickým Německem a následným uzavřením českých vysokých škol.

\section{Divadelní výzkum v období války}

Po rozšíření fašistických a autoritářských režimů v Evropě v polovině třicátých let zaujal PLK stanovisko k nebezpečí fašizace společnosti. Eisner, Fischer, Silberstein a další byli otevřenými antifašisty, což dali najevo v řadě článků. ${ }^{11}$ Mukařovský a Fischer podepsali výzvu Společnosti československých spisovatelů na obranu proti agresi (českých) fašistů

9 Růt o rok později, tedy v roce 1936, napíše disertaci o rozhlasové hře, ve které se opírá o terminologii a koncepci estetiky dramatického umění Otakara Zicha (viz RŮT 1964).

10 Podle dochované korespondence (MUKAŘOVSKÝ 2008a: 173; 2008b: 192) Mukařovský sám nakonec upravil a vylepšil původní Brušákův text, jelikož autor byl od roku 1938 na stipendiu ve Francii (HAVLÍČKOVÁ KYSOVÁ 2010: 31). Další verze tohoto textu vyšla v Programu D 39.

11 Viz dobovou analýzu vlivu nacismu na německý jazyk Ingeborg Seidel-Slottové ve Slově a slovesnosti (SEIDLOVÁ-SLOTTYOVÁ 1936) a její Eisnerovu reflexi (EISNER 1936) anebo Silbersteinovu kritiku rasových teorií a Norimberských zákonů v knize Vývoj rasových teorii (SILBERSTEIN 1936). 
(Projev spisovateli̊ 1934). Helfert s Václavkem patřili k iniciátorům manifestu Věrni zůstaneme, který vzešel z okruhu brněnského levicového sdružení Blok, v němž přední osobnosti české kultury požadovaly obranu demokracie proti fašismu (MED 2010: 104) a který podepsali kromě jiných Mukařovský a Havránek.

Narůstající politické napětí v Evropě i uvnitř státu, vrcholící rozpadem ČSR po Mnichovské dohodě v září 1938, způsobilo předěl v existenci Kroužku. Někteří z jeho členů, jako muzikolog Gustav Becking nebo slavista Ferdinand Liewehr, se připojili k NSDAP a opustili PLK. Beking sám zahynul pravděpodobně při lynčování Němců v pražských ulicích v posledních dnech války (HAVRÁNKOVÁ a PETKEVIČ 2015: 52). Emil Utitz a Oskar Kraus, kromě PLK organizovaní v Pražském filosofickém kroužku, byli deportováni do koncentračních táborů, další člen PLK a Pražského filosofického kroužku, slavista a politický filosof Leopold Silberstein byl zavražděn nacisty v Estonsku. Trubeckoj zemřel ve Vídni po nacistickém výslechu, Fischer umřel po infarktu poté, co se dozvěděl o Anšlusu, a jeho bratr Jan, docent dějin filosofie na UK a sociálnědemokratický politik, zemřel v nacistické věznici v Neubrandenburku (THIROUDIN-DÉVERCHÈRE 2002: 187-188). Alfréd Bém, literární vědec, ruský emigrant a pracovník Ruské lidové (svobodné) univerzity v Praze byl zatčen v květnu 1945 v Praze sovětskou tajnou policií a od té doby je jeho další osud neznámý (BUBENÍKOVÁ a VACHALOVSKÁ 1995: 8). Pravděpodobně byl zavražděn, podobně jako slavista Nikolaj Durnovo. Ten se na začátku třicátých let vrátil do Ruska, protože v Praze nemohl najít práci, v roce 1933 byl ve vykonstruovaném procesu obviněn z kontrarevoluční činnosti, odsouzen k nuceným pracím a po zpřísnění trestu v roce 1937 zastřelen (MACH 2012: 38). Jakobson utekl z ČSR do Dánska, odtud do Švédska a později do USA. Bogatyrev se vrátil do SSSR. Petr Savickij, který po roce 1939 dále pracoval na Německé univerzitě v Praze, byl údajně odtud nucen odejít v roce 1941 poté, co prohlásil, že sovětská armáda je neporazitelná (MACH 2012: 39). Veltruský, který po zavření vysokých škol neformálně studoval u Mukařovského a byl na začátku čtyřicátých let snad nejmladším členem PLK, se pravděpodobně zapojil do odboje a zúčastnil se Pražského povstání (HOSKOVEC 2012: 206-229), zatímco Jirát zemřel během povstání na nedostatek inzulínu. Události po nástupu KSČ k moci po únoru 1948 na první pohled nejsou tak drastické, někteří členové alespoň z počátku vychází dobře s novým režimem, ovšem někteří jsou umlčováni, např́ílad Antonín Grund spáchal v důsledku politických tlaků sebevraždu (MACHEK 2011: 181).

Paradoxně došlo právě v období války k intenzivnímu rozvoji českého myšlení o divadle, Kroužek přitom zdaleka nebyl jedinou institucí publikující a pořádající přednášky o teatrologických tématech. Znovu, jako v případě střetů ohledně jazykového purismu na počátku třicátých let, měl Kroužek pole pro obhajobu svých principo̊ vůči konkurenci. V tomto případě soupeřil s Literárně-historickou společností československou, založenou v roce 1935.

V květnu 1940 otevřel operní režisér Ferdinand Pujman svým „Rozhovorem o divadelní vědě“ cyklus přednášek organizovaný Literárněhistorickou společností česko- 
slovenskou (Zpráva o činnosti Literárně-historické společnosti v Praze v VI. Správním roce 1940/41). Ačkoliv byl Pujman modernisticky orientovaný režisér s hlubokou znalostí estetiky, Mukařovský, sám člen této společnosti, sarkasticky označil jeho přednášku za „dadaistický“ útok proti tehdy nově vydané Bogatyrevově knize Lidové divadlo české a slovenské a proti divadlu Emila Františka Buriana (MUKAŘOVSKÝ 2008c: 210-211). Pujman také navrhoval založení divadelní sekce při Literárněhistorické společnosti československé. Vedle něj byli do přípravného výboru zvoleni Mukařovský a rozhlasový dramaturg Václav Sommer.

Jako akci proti ovládnutí divadelněvědných témat Literárněhistorickou společností československou navrhl Mukařovský Honzlovi, aby připravil přednášku o divadle a recenzoval nové knihy o divadle. Honzl promluvil v PLK 1. července 1940 na téma "Jevištní dílo jako soubor znaků“. Jeho výklad byl téhož roku otištěn ve Slově a slovesnosti pod názvem „Pohyb divadelního znaku“ (HONZL 1940b) a stal se základem moderní české divadelní teorie. V letech 1940-1943 Honzl - a spolu s ním i Veltruský a Mathesius - publikovali ve Slově a slovesnosti několik recenzí divadelních publikací. Samozřejmě mezi nimi nechyběla Pujmanova Zhudebněná mateřstina. Přestože redaktoři Slova a slovesnosti neměli v roce 1939 problém s uveřejněním ukázky z Pujmanovy knihy, Honzl byl o rok později k Pujmanovi natolik kritický (HONZL 1940c), že vyprovokoval jeho polemickou reakci. ${ }^{12}$

Teatrologická organizace, plánovaná v rámci aktivit Literárněhistorické společnosti československé, nakonec nevznikla. Až v roce 1942 ustavila Umělecká beseda Sdružení pro divadelní tvorbu. Jejím prvním předsedou se stal Albert Pražák, tehdy stojící v čele Literárněhistorické společnosti, kterého ale pro vytíženost vystřídal právě zmíněný Pujman.

Společnost pro divadelní tvorbu měla „zkoumat dějiny i současný stav našeho divadla ve všech jeho projevech a vztazích $\mathrm{k}$ životu veřejnému, šírit znalost divadelních umění a lásku k němu v nejširších vrstvách, pečovat, aby se co nejtěsněji sblížilo s ostatními uměními, starat se o zachování a zveřejnění divadelních památek a podporovat původní divadelní tvorbu“ (KRS 1945: 60). Sdružení také mělo soustředit představitele divadelního umění, jiným úkolem bylo pečovat o odkaz českého modernistického režiséra K. H. Hilara.

Přestože v tomto období byla česká společnost pod největším nacistickým útlakem, Sdružení plánovalo a pořádalo přednášky věnované divadelní problematice (například jevištní řeč, konvence současného divadla a aktuální otázky divadla atd.). Na podzim 1943 uspořádalo cyklus přednášek „Ode dneška k základům divadla“, „v němž se v shrnujícím přehledu a v historické perspektivě probíraly nejdůležitější problémy jednotlivých složek divadelního díla se zvláštním zřetelem k současné divadelní konvenci“ (KRS 1945). Vystoupili zde Josef Träger, Karel Svoboda, Olga Srbová, Miroslav Kouřil, Mirko Očadlík, Jiří Frejka, Jan Kopecký, Ferdinand Pujman. O přednášky byl údajně velký zájem, navštěvovali je členové PLK i široká umělecká veřejnost (Dopis B. Trnky Sdruženi

12 Honzl rovněž napadl Weingartovo pojetí jazyka ve zvukovém filmu (WEINGART 1935), krátce poté, co Weingart odešel z Kroužku (HONZL 1936). 
pro divadelni tvorbu z 5. 11. 1943). Během války zde vznikl záměr vydávat speciální divadelní edice a divadelní časopis, řada přednášek byla publikována knižně hned po konci války (KRS 1945).

Na jaře 1944 připravilo sdružení večery „Živých divadelních otázek“, kde byly předneseny referáty k diskuzi. O výchově mladých herců mluvili Olga Srbová a Jiří Frejka, o smyslu dnešní divadelní práce přednášel Josef Träger (3. 4. 1944) (TRÄGER 1945), o překladech a úpravách her Ivo Liškutin a Karel Kraus a o dramaturgii a dramatizaci Jiří Hájek (květen 1944) (HÁJEK 1946) a Michal Sedloň, o „dramomanii“ a českých dramatických novinkách Vítězslav Kocourek a Jan Kloboučník, o divadelním provozu a divadelní tvorbě Antonín Kurš, Jaroslav Novotný a Jan Kopecký. Členové sdružení na jaře 1944 připravili mj. vydávání edice Divadelní perspektivy, za války v rámci této edice vyšla jen Frejkova studie „Jevištní řeč a verš tragédie“ a Kalistova „Barokní tradice v našem divadle novodobém“, další studie byly publikovány po roce 1945. Z těchto kruhů vzešel poválečný Divadelni zápisnik, který byl zamýšlen jako odborný časopis, který zároveň osloví širší divadelní obec (KRS 1945).

Další rozpor mezi Kroužkem a Literárněhistorickou společností vznikl na jaře 1944, kdy Literárněhistorická společnost uspořádala sérii přednášek o publikaci Čteni o jazyce a poezii, kterou vydal PLK. Zde uveřejněná studie - fakticky disertace - Jiř́ího Veltruského Drama jako básnické dílo byla na jedné ze schůzí představena filologem a estetikem Karlem Svobodou takovým zpo̊sobem, že toto vystoupení Veltruského mentor Mukařovský nazval „muzeem kretenismu“ (MUKǍ̌OVSKÝ 2008e: 320-321).

Z této perspektivy jsou texty Mukařovského, Veltruského nebo Honzla nejen teoretickou reflexí divadelní tvorby jako takové, ale také praktickými kroky k obsazení pozic v nově vytvářejícím se poli intelektuální produkce a přípravou k ustavení samostatného vědeckého univerzitního pracoviště v roce 1948 (v témže roce přesunuté na DAMU). ${ }^{13}$ Od konce války připravovali Mukařovský, Honzl, Burian a Kouřil Divadelni slovnik naučný (DVǑ̌ÁK 1965: 156), jenž měl vycházet v edici Knihovna divadelního prostoru, založené Kouřilem během války. Spolu s Miroslavem Kouřilem (1945) v rámci této edice publikovali jeho generační souputníci Antonín Dvořák (1946, 1947) a Jaroslav Pokorný (1946), kteří ve svých studiích shrnuli a etablovali zjednodušený strukturalismus, založený hlavně na textech Mukařovského a Honzla, jako hlavní proud poválečného myšlení o divadle. Mukařovský chtěl v PLK uspořádat cyklus přednášek, který by vycházel z hotových hesel tohoto divadelního slovníku (MUKǍ̌OVSKÝ 2008f: 373). Sám se věnoval uměleckým otázkám v takzvané ilegální divadelní škole, kterou organizovali mladí divadelníci spojení s Divadélkem pro 99. Zdejších setkání se účastnili i Honzl, Veltruský, Teige a z mladých divadelníků Kouřil, Pokorný a Dvořák. Tato skupina měla pracovat na rešerších pro zmíněný divadelní slovník. Vedle divadla byl podstatným tématem výkladů marxismus (DVOǨ́́K 1965: 154-155).

13 Kurzy z divadelní teorie a historie vyučoval už ve třicátých letech na Německé univerzitě v Praze Arnulf Pergler, který se stal mimořádným profesorem pro divadelní vědu v roce 1940 (KONRÁD 2011: 217). Ačkoliv je o Perglerovi málo známo, čeští vědci - rovněž ti, kteří uplatňovali strukturalistický př́istup - jeho texty znali (viz BUNDÁLEK 1948: 38). 


\section{Po válce: strukturalismus jako konsensus a změna stylů}

Po konci druhé světové války založil Mukařovský divadelní sekci v Semináři estetiky na Filozofické fakultě Univerzity Karlovy, Veltruský zde získal místo asistenta. Už v zimním semestru roku 1945 otevřel Mukařovský kurz o teorii jevištní dikce. ${ }^{14}$ Ve stejné době ustavil Honzl Studio Národního divadla, které mělo poskytnout prostor začínajícím umělcům. Oba uvažovali o spolupráci obou nových institucí, která měla být založena na vzájemném obohacení a spojení teorie a praxe divadla. Členové studia se měli účastnit projektů semináře a seminaristé zkoušek ve Studiu, stejně jako různých komisí ve Studiu, měli se zabývat soustavnými rozbory a rozhovory o inscenacích (VELTRUSKÝ 1945: 18). Jak připomněl Ondřej Sládek, Mukařovského Estetický seminář na UK navštěvovali studenti, kteří se později stali významnými osobnostmi divadelní a literární vědy, jako například František Černý nebo Miroslav Kačer, herec Radovan Lukavský, režisér Otomar Krejča a další (SLÁDEK 2014: 123). Honzl také založil a redigoval časopis Otázky divadla a filmu, který se - alespoň zpočátku - stal publikační platformou strukturalistického myšlení o divadle.

Bezprostřední význam Kroužku na proměnu myšlení o divadle a ustavení divadelních studií je zřejmý u Bratislavského lingvistického kroužku (1945-1951), jehož přední členové Eugen Pauliny a Alexander Isačenko byli členy PLK (VYKYPĚLOVÁ 2005). V jejich časopise Slovo a tvar vyšlo několik článků, jejichž autoři uplatnili strukturální přístup k divadlu. Především dramatik a teoretik Peter Karvaš dokázal Mukařovského a Honzlovy dílčí studie obohatit o sociologický přístup a v roce 1948 vytvořit skutečně celistvou strukturalistickou teorii divadla. Jeho Úvod do základných problémov divadla, vydaný organizací slovenský amatérských (!) divadelníků (KARVAŠ 1948), nazval Michael Quinn „nejúplnější československou syntézou Pražské školy divadelní teorie“ (QUINN 1995: 222-223). Bogatyrev se po roce 1945 pravděpodobně podílel na ustavení Kabinetu pro výzkum západoslovanského divadla v Moskvě (ADÁMEK 1947: 354-355).

Strukturalistický postoj k divadlu se stal všeobecně přijímaným př́istupem k divadlu po konci druhé světové války. K tomuto uznání a rozšiřrení došlo mimo jiné proto, že si tento koncept během války osvojila nejmladší generace divadelníků, z níž vzešla skupina tvůrců, kteří hledali vlastní styl stejně jako místo v českém divadelnictví. Dvořák, Pokorný a Kouřil vydali několik rozsáhlých syntetických studií, v nichž uplatnili strukturální př́ístup k divadlu, angažovali se rovněž v zestátnění divadel po roce 1945, př́ípravách Divadelního zákona, jako technokrati komunistického režimu se účastnili etablování stalinismu po roce 1948.

Otázky nové citlivosti a estetiky, rozdělení práce v divadle a pocit odklonu od meziválečné minulosti se staly předměty válečných a poválečných debat (viz FREJKA 1945; HÁJEK 1946; CHALUPECKÝ 1940, 1946; SRBOVÁ 1941). Ačkoliv př́íspěvky členů PLK k myšlení o divadle vychází z bohaté meziválečné kultury, domnívám se, že jsou

14 Mukařovský zamýšlel s Honzlem spolupracovat při studiu umělecké deklamace už v roce 1942 (MUKAŘOVSKÝ 2008d: 236). 
zejména příznakem „změny stylư“ (SRBOVÁ 1941) než bezprostředním zobecněním meziválečné avantgardy a jejím prostým pokračováním.

A tak je zřejmě nejvýznamnějším znakem divadelní kultury raných čtyřicátých let (sebe)reflexivní obrat mezi divadelníky. Jak jsem ukázal výše, sebereflexivita nebyla jen specifikem tvůrců spojených s PLK, ale byla širším kulturním jevem. Proto shrnuji: strukturální přístup $\mathrm{k}$ divadlu byl formulován na konci třicátých let a během druhé světové války díky aktivistickému přístupu k vědě, úzké spolupráci divadelních tvůrců a vědců a polemické a popularizační povaze klíčových textů, které byly určeny mimo jiné oponentům z oblasti divadelní teorie a praxe, motivovány potřebou vysvětlit moderní umění moderními prostředky a dát tyto poznatky k dispozici veřejnosti.

\section{Bibliografie}

ADÁMEK, Vladimír. 1947. Praha-Moskva [Prague-Moscow]. Divadelni zápisník 3 (1. 10. 1947): 7: 353-357.

Acta linguistica. Prager Presse 18 (25. 10. 1938): 264: 7.

BĚLOŠEVSKÁ, Ljubov (ed.). 2000. Kronika kulturniho, vědeckého a společenského života ruské emigrace v Československé republice: Chronika kulturnoj, naučnoj i ob̌̌čestvennoj žizni russkoj emigracii $v$ Čechoslovackoj respublike [Chronicle of the Cultural, Scholarly and Social Life of Russian Emigrants in the Czechoslovakia]. Praha: Slovanský ústav AV ČR, 2000.

BERGMANOVÁ, Marie. 1937a. Jarní festival 1937 [Spring Festival od 1937]. Program D 38 (24. 9. 1937): 1: 39-41.

mb [BERGMANOVÁ, Marie]. 1937b. Živý tanec [Living Dance]. Program D 38 (25. 11. 1938): 5: 127. BOGATYREV, Petr. 1937a. Lidové divadlo [Folk Theatre]. Program D 37 (31. 3. 1937): 8: 188-195. BOGATYREV, Petr. 1937b. Puškin a lidové divadlo [Pushkin and Folk Theatre]. Program D 37 (26. 1. 1937): 6: 150-152.

BROKLOVÁ, Eva. 2003. Emanuel Rádl mezi Čechy a Němci [Emanuel Rádl Between the Czechs and Germans]. In Emanuel Rádl. O německé revoluci; K politické ideologii sudetských Němců [The German Revolution: To the Political Ideology of Sudeten Germans]. Eva Broklová (ed.). Praha: Masarykův ústav AV ČR, 2003: 7-24.

BRUŠÁK, Karel. 1939. Čínské divadlo [Chinese Theatre]. Program D 39 (23. 2 1939): 97-104. BUBENÍKOVÁ, Miluša a Lenka VACHALOVSKÁ (edd.). 1995. Alfréd Ljudvigovič Bém (18861945?): Bibliografie [Alfréd Ljudvigovič Bém (1886-1945?): A Bibliography]. Praha: Národní knihovna České republiky, 1995.

BUNDÁLEK, Karel. 1948. Skladba dramatického prostoru [Construction of the Dramatic Space]. Program Státního divadla v Brně 3 (10. 4. 1948): 11: 325-327; 4 (1. 11. 1948): 3: 36-38.

BURIAN, Emil František. 1939. Příspěvek k problému jevištní češtiny [To the Issue of the Czech Spoken From the Stage]. Slovo a slovesnost 5 (1939): 1: 24-32.

BYDŽOVSKÁ, Lenka a kol. 1996. Chronologie [A Chronology]. In Lenka Bydžovská a Karel Srp (edd.). Český surrealismus 1929-1953 [Czech Surrealism (1929-1953)]. Praha: Argo a Galerie hlavního města Prahy, 1996. 
ČERMÁK, Petr, Claudio POETA a Jan ČERMÁK. 2012. Pražský lingvistický kroužek v dokumentech [The Prague Linguistic Circle in Documents]. Praha: Academia, 2012.

ČERNÝ, František. 1952. Mukařovský a české divadlo [Mukařovský and the Czech Theatre]. In Bohuslav Havránek a František Černý (edd.). Janu Mukařovskému k šedesátce [To Jan Mukařovský’s 60th Birthday]. Praha: Československý spisovatel, 1952: 74-79.

Der 'Pražský linguistický kroužek'. 1932. Prager Presse 12 (1. 11. 1932): 298: 8.

DVOŘÁK, Antonín. 1965. Divadelníci na nedivadelní frontě [Theatre People Outside Theatre]. In František Černý (ed.). Theater - Divadlo [Theater - Theatre]. Praha: Orbis, 1965: 152-158.

DVOŘÁK, Antonín a kol. 1944. Kdo vytváři divadlo? O autorstvi na jevišti [Who Creates Theatre? The Authorship on the Stage]. Praha: Ústav pro učebné pomůcky průmyslových a odborných škol, 1944.

DVOǨÁK, Antonín. 1946. Dialektické rozpory v divadle [Dialectic Divergencies in Theatre]. Praha: Otto Girgal, 1946.

DVOǨÁK, Antonín. 1947. Divadelní a dramatický prostor [Theatrical and Dramatic Space]. Praha: Ústav pro učebné pomůcky průmyslových a odborných škol, 1947.

D 37. 1937. Výstava československé avantgardy [Exhibition of the Czech Avant-Garde]. Praha: Československý kompas, 1937.

EFFENBERGER, Vratislav. 1974. Osvobozené divadlo [The Liberated Theatre]. Rukopis [Manuscript]. Praha: Divadelní ústav, 1974.

EHLERS, Klaas-Hinrich. 1997. Die Slavische Rundschau 1929-1940. Brucken: Germanistisches Jahrbuch Tschechien-Slowakei 5 (1997): 149-204.

EHLERS, Klaas-Hinrich. 2001. Die Gründung der Germanoslavica. Germanoslavica: Zeitschrift für germano-slawische Studien. Praha: Slovanský ústav 8 (13) (2001): 1: 83-103.

EHLERS, Klaas-Hinrich. 2003. Prager Deutsche im Prager Zirkel. Ein überblick. In Marek Nekula (ed.). Prager strukturalismus: Methodologische Grundlagen. Heidelberg: Winter, 2003: 49-77.

EHLERS, Klaas-Hinrich. 2005. Strukturalismus in der deutschen Sprachwissenschaft: die Rezeption der Prager Schule zwischen 1926-1946. Berlin: de Gruyter, 2005.

Ein „Ethnographischer Zirkel“. Slavische Rundschau 2 (Januar 1930): 1: 71.

P. E. [EISNER, Paul]. 1936. Blut und Leben. Prager Presse 16 (20. 6. 1936): 169: 8.

FREJKA, Jiří. 1937. Verše „Borise Godunova“ na jevišti (K jeho inscenaci na Národním divadle) [„Boris Godunov“ on the Stage: To the National Theatre Production]. Slovo a slovesnost 3 (1937): 1: 50-53.

FREJKA, Jiří. 1945. Železná doba divadla [The Iron Age of Theatre]. Praha: Melantrich, 1945.

GESEMANN, Gerhard. 1933. Ein bulgarischer Espensänger im Tonfilm. Slavische Rundschau 5 (20. 4. 1933): 3: 143-155.

GONĚC, Vladimír. 1993. Ruská filosofická emigrace v Československu [Russian Philosophical Emigration in the Czechoslovakia]. Slovanský přehled 79 (1993): 1: 38-44.

HÁJEK, Jiří. 1946. Generace na rozhrani [Generation in Between]. Praha: Mladá fronta, 1946.

HAVLÍČKOVÁ KYSOVÁ, Šárka. 2010. Znakové systémy asijských divadelních forem v českém myšlení o divadle [Sign systems of Asian theatre forms in context with Czech thinking on theatre]. Theatralia 13 (2010): 2: 24-39.

HAVRÁNEK, Bohuslav a Jan MUKAŘOVSKÝ (edd.). 1942. Čteni o jazyce a poesii [Language and Poetry Reader]. Praha: Družstevní práce, 1942. 
HAVRÁNKOVÁ, Marie. 1990. Život a činnost v datech [Life and Activities in Facts and Figures]. Slavica Pragensia XXIV. Acta universitatis carolinae: Pilologica (1990): 1-3: 299-307.

HAVRÁNKOVÁ, Marie a Vladimír PETKEVIČ. 2015. Pražská škola v korespondenci [The Prague School in Letters]. Praha: Karolinum. 2105.

HERRMANN, Konrad. 2015. Leopold Silberstein: Slawist und Philosoph. Berlin: be.bra wissenschaftliche Verlag, 2015.

HONZL, Jindřich. 1936. Reakční názory o mluvicím filmu [Reactionist Opinions About Sound Film]. Slovo a slovesnost 2 (1936): 1: 56-61.

HONZL, Jindřich. 1940a. Nad Diderotovým paradoxem o herci [On Diderot's Paradox of the Actor]. Program D 40 (8. 2. 1940): 4: 81-84.

HONZL, Jindřich. 1940b. Pohyb divadelního znaku [The Mobility of the Theatrical Sign]. Slovo a slovesnost 6 (1940): 4: 177-188.

HONZL, Jindřich. 1940c. Pujmanovo pojetí staročeského dramatu církevního [Metoda Pujmanova výkladu...] [Pujman's Concept of the Old Czech Liturgical Drama (The method of Pujman's explanation...)]. Slovo a slovesnost 6 (1940): 4: 230-231.

HORA, Josef. 1997. Dopis Josef Hory Romanu Jakobsonovi 19. 8. 1937 [A Letter From Josef Hora to Roman Jakobson, Aug 19, 1937]. Alena Morávková (ed.). Praha-Litomyšl: Paseka, 1997.

HOSKOVEC, Tomáš. 2010. Klub a Kroužek: Úvahy o dynamice české filologie [The Club and the Circle: Thoughts on the Dynamics of Czech Philology]. In XXIII. ročenka Kruhu modernich filologü. Moderni filologie na prahu třetího tisícileti [XXIIIrd Anthology of the Circle of Modern Philologists. Modern Philology on the Threshold of the Thirt Millenium]. Pelhřimov: Kruh moderních filologů, 2010: 26-40. Citováno z upravené verze poskytnuté autorem [Quoted according to a new version provided by the author].

HOSKOVEC, Tomáš. 2012. Jiří Veltruský (1919-1994). A journey through life with semiotics. In Jiří Veltruský. An approach to the semiotics of theatre. Brno: Ústav divadelních studií FF MU \& Pražský lingvistický kroužek, 2012: 206-229. Travaux du Cercle linguistique de Prague 6.

CHALUPECKÝ, Jindřich. 1940. Svět v němž žijeme [The World We Live In]. Program D 40 (8. 2. 1940): 4: 88-89.

CHALUPECKÝ, Jindřich. 1946. Konec moderní doby [The End of the Modern Age]. Listy pro umèni a filosofii 1 (15. 4. 1946): 1: 7-23.

CHVATÍK, Květoslav. 1968. Avantgarda a strukturalismus [The Avant-Garde and Structuralism]. In Viera Rybárová (ed.). Problémy literárnej avantgardy [Problems of Literary Avant-Garde]. Bratislava: Vydavatelsto SAV, 1968: 85-94.

ILLING, Frank. 2001. Jan Mukařovský und die Avantgarde: Die strukturalistische Ästhetik im Kontext von Poetismus und Surrealismus, Bielefeld: Aisthesis, 2001.

JAKOBSON, Roman. 1929. Romantické všeslovanství - nová slavistika [The Romantic Panslavism - New Slavic Studies]. Čin 1 (31. 10. 1929): 1: 10-12.

JAKOBSON, Roman. 1933. Ukázky z chystané monografie o šlágrech V \& W [Extracts From the Planned Monograph on the Hits by Voskovec and Werich]. In Tucet melodii z Osvobozeného divadla [Dozen Melodies From the Liberated Theatre]. Praha: Hudební matice Umělecké Besedy, 1933.

JAKOBSON. Roman. 1937a. Dopis Jiřímu Voskovcovi a Janu Werichovi o noetice a semantice švandy [An Open Letter to Jiří Voskovec and Jan Werich About the Epistomology and Seman- 
tics of Fun]. In Josef Träger (ed.). Deset let Osvobozeného divadla 1927-1937 [Ten Years of the Liberated Theatre (1927-1937)]. Praha: Fr. Borový, 1937: 27-34.

JAKOBSON, Roman. 1937b. Puškin v realistickém světle [Pushkin in the Light of Realism]. Program D 37 (26. 1. 1937): 133-136.

JAKOBSON, Roman. 1997. Z korespondence [Letters]. Alena Morávková (ed.). Praha-Litomyšl, 1997.

Jiří Veltruský. 2010. In Československé dokumentačni středisko [The Czechoslovak Documentation centre] [online]. 2010. Praha: Československé dokumentační středisko, o. p. s. Dostupné z: <http://csds.cz/cs/g6/1501-DS.html>.

JIRÁT, Vojtěch, 1939. Klicpera aneb o divadelníkovi [Klicpera or About a Theatre Person]. Program D 40 (24. 10. 1939): 1: 30-32.

JIRÁT, Vojtěch. 1940. Hra a skutečnost: Vývoj a hlubší smysl jednoho motivu [Play and Reality: The Development and Inner Meaning of A Motif]. Program D 41 (1. 11. 1940): 4: 117-120.

KARVAŠ, Peter. 1948. Úvod do základných problémov divadla [An Introduction to the Basic Theatre Issues]. Turčianský Svätý Martin: Ústredie slovenských ochotníckých divadiel, 1948.

KONRÁD, Ota. 2011. Dějepisectví, germanistika a slavistika na Německé univerzitě v Praze 1918-1945 [History, German Studies, and Slavic Studies at the Prague German University Between 1918 and 1945]. Praha: Karolinum, 2011.

Krs. 1945. Činnost Sdružení pro divadelní tvorbu v Umělecké besedě [Actvities of the Theatre Club of the Art Association 'Umělecká beseda']. Divadelni zápisnik 1 (1945): 1-2: 60-62.

Kruh přátel D 40 [Friends of the Theatre D 40]. Program D 40 (7. 3. 1940): 5: 120.

KUDLÁČKOVÁ, Helena. 2001. Čapkova přijatá korespondence - další svědectví o pátečnících [Čapek's Received Letters: Another Testimony About the 'Pátečníci' Group]. In Pavel Janáček (ed.). Pátečníci a Karel Poláček [The 'Pátečníci' Group and Karel Poláček]. Boskovice: František Šalé - ALBERT, 2001: 48-51.

LUŽA, Radomír. 2001. Československá sociální demokracie: Kapitoly z let exilu 1948-1989 [The Czech Social Democratic Party: Chapters From the Exile Years 1948-1989]. Praha - Brno: Československé dokumentační středisko a nakladatelství Doplněk, 2001.

Mgr. [MÁGR, Antonín Stanislav]. 1932. Dichterische Sprache und Schriftsprache. Prager Presse 12 (11. 2. 1932): 42: 8.

Mgr. [MÁGR, Antonín Stanislav]. 1935. Die Erscheinung Hálek’s in zwei Aspekten. Prager Presse 15 (10. 4. 1935): 99: 6.

MACHEK, Václav. 2011. Korespondence [Letters]. Vít Boček a Petr Malčík (edd.). Svazek I. [Vol. 1]. Praha: Lidové noviny, 2011.

MACH, Jaromír. 2012. Ruští intelektuálové v emigraci a jejich institucionální základna v Praze (na modelu Ruské svobodné univerzity a přidružených institucí, 1923-1945) [Russian Emigrant Intellectuals and Their Institutional Background in Prague Explained on the Example of the Free Russian University and the Associated Institutions (1923-1945)]. Disertace, Filozofická fakulta Masarykovy univerzity. Brno: Masarykova univerzita [Dissertation, Faculty of Arts, Masaryk University in Brno], 2012. Dostupné z 〈http://is.muni.cz/th/18830/ff_d/disertace_J._Mach.pdf〉.

Masaryk a ř $\check{e}$ [Masaryk and Language]. 1931. Praha: Pražský linguistický kroužek, 1931.

MATHESIUS, Vilém. 1925. Kulturni aktivismus: anglické paralely k českému životu [Cultural Activism: English Parallels to the Czech Way of Life]. Praha: Gust. Voleský, 1925. 
MATHESIUS, Vilém. 1940. Výslovnost jako faktor sociální a funkční [Pronunciation as a Social and Functional Factor]. Program D 41 (1. 10. 1940): 3: 71-74.

MATHESIUS, Vilém. 1945. Možnosti, které čekaji: epištoly o tvořivém životě [Awaiting Possibilities: Epistles About a Creative Life]. Praha: Jan Leichter, 1945.

MED, Jaroslav. 2010. Literární život ve stínu Mnichova (1938-1939) [Literature in the Shadow of the Munich Pact (1938-1939)]. Praha: Academia, 2010.

MUKǍ̌OVSKÝ, Jan. 1935a. Dialektické rozpory v moderním uměni [Dialectic Divergencies in Modern Art]. Praha: vlastní náklad [self financed], 1935.

MUKAŘOVSKÝ, Jan. 1935b. Vztah mezi sovětskou a československou literární vědou [The Relation Between Soviet and Czech Literary Studies]. Země sovětu 4 (březen 1935): 1: 10-15.

MUKǍ̌OVSKÝ, Jan. 1937a. O jevištním dialogu [On the Stage Dialogue]. Program D 37 (31. 3. 1937): 8: 232-234.

MUKAŘOVSKÝ, Jan. 1937b. Stav naší dnešní estetiky [The Current Situation of the Cech Aesthetics]. Čin 9 (22. 4. 1937): 8: 70-71.

MUKAŘOVSKÝ, Jan. 1937c. Šaldova dramatičnost [Šalda Dramatic(al)]. Listy pro uměni a kritiku 5 (27. 5. 1937): 9-10: 193-196.

MUKAŘOVSKÝ, Jan. 1938. K noetice surrealismu v malířství [To the Noetics of Surrealism in Painting]. Slovenské smery umelecké a kritické 5 (červen 1938): 6-8: 226-230.

MUKǍ̌OVSKÝ, Jan (ed.). 1938. Torso a tajemství Máchova díla [Fragmentariness and Mystery of Mácha's Works]. Praha: Fr. Borový, 1938.

MUKAŘOVSKÝ, Jan. 1941. K dnešnímu stavu teorie divadla [On the Current State of Theory of Theatre]. Program D 41 (28. 1. 1941): 7: 229-242.

MUKǍ̌OVSKÝ, Jan. 1946a. Jindřich Štýrský. In 364. výstava Spolku výtvarných umèlců Mánes 4. 25. dubna 1946 [364th Exhibition of the Association of Visual Artists 'Mánes', Apr 4-25, 1946]. Praha: SVU Mánes, 1946: 4-8.

MUKAǨOVSKÝ, Jan. 1946b. Toyen za války [Toyen During the War]. Doba 1 (1946): 2: 46-48.

MUKAŘOVSKÝ, Jan. 2008a. Dopis Bohuslavu Havránkovi 29. 11. 1938 [A Letter to Bohuslav Havránek, Nov 29, 1938]. In Marie Havránková (ed.). Pražský lingvistický kroužek v korespondenci [The Prague Linguistic Circle in Correspondance]. Praha: Academia, 2008.

MUKǍ̌OVSKÝ, Jan. 2008b. Dopis Bohuslavu Havránkovi 10. 5. 1939 [A Letter to Bohuslav Havránek, May 10, 1939]. In Marie Havránková (ed.). Pražský lingvistický kroužek v korespondenci [The Prague Linguistic Circle in Correspondance]. Praha: Academia, 2008.

MUKǍ̌OVSKÝ, Jan. 2008c. Dopis Mukařovského Havránkovi 22. 5. 1940 [A Letter From Mukařovský to Havránek, May 22, 1940]. In Marie Havránková (ed.). Pražský lingvistický kroužek v korespondenci [The Prague Linguistic Circle in Correspondance]. Praha: Academia, 2008.

MUKǍ̌OVSKÝ, Jan. 2008d. Dopis Bohuslavu Havránkovi 13. 1. 1942 [A Letter to Bohuslav Havránek, Jan 13, 1942]. In Marie Havránková (ed.). Pražský lingvistický kroužek v korespondenci [The Prague Linguistic Circle in Correspondance]. Praha: Academia, 2008.

MUKAŘOVSKÝ, Jan. 2008e. Dopis Bohuslavu Havránkovi 22. 3. 1944 [A Letter to Bohuslav Havránek, Mar 22, 1944]. In Marie Havránková (ed.). Pražský lingvistický kroužek v korespondenci [The Prague Linguistic Circle in Correspondance]. Praha: Academia, 2008. 
MUKǍ̌OVSKÝ, Jan. 2008f. Dopis Bohuslavu Havránkovi 10. 4.1945 [A Letter to Bohuslav Havránek, Apr 10, 1945]. In Marie Havránková (ed.). Pražský lingvistický kroužek v korespondenci [The Prague Linguistic Circle in Correspondance]. Praha: Academia, 2008.

NEZVAL, Vítězslav (ed.). 1935. Ani labut' ani Lưna [Neither the Swan Nor the Moon]. Praha: Concordia, 1935.

(nn.). Zur Orthoepie des Tschechischen. Prager Presse 15 (16. 5. 1935): 132: 8.

NOVÁK, Bohumil. 1940. Kruh přátel D 40 [Friends of the Theatre D 40]. Program D 40 (9. 1. 1940): 3: 80 .

NOVÁK, Bohumil. 1965. Kruh přátel divadla E. F. Buriana [Friends of the E. F. Burian's Theatre]. In František Černý (ed.). Theater - Divadlo [Theater - Theatre]. Praha: Orbis, 1965: 43-51.

„O Pražském linguistickém kroužku. Pǐse Bohumil Trnka“ [On the Prague Linguistic Circle by Bhumil Trnka]. [1940]. Masarykův ústav a Archiv Akademie věd České republiky. Fond Pražský Lingvistický kroužek [the Prague Linguistic Circle collection], sg. 16.

QUINN, Michael. 1995. Satellite drama: Imperialism, Slovakia and the Case of Peter Karvaš. In J. Ellen Gainor (ed.). Imperialism and Theatre. London, New York: Routledge, 1995: 214-229.

PATELKA, Josef. 1972. The Prague School and Studies in the Language of Comerce. In V. Fried (ed.). The Prague School of Linguistics and Language Theaching. London: Oxford University Press, 1972: 211-223.

PETŘíČEK, Miroslav. 1996. Štýrský v pohledu Mukařovského: Marginální poznámky ke strukturalismu a surrealismu [Štýrský Viewed by Mukařovský: Marginal Notes to Structuralism and Surrealism]. In Lenka Bydžovská, Karel Srp (edd.). Český surrealismus 1929-1953 [Czech Surrealism (1929-1953)]. Praha: Argo a Galerie hlavního města Prahy, 1996: 366-369.

PIORECKÁ, Kateřina a Karel PIORECKÝ. 2014. Praha avantgardní: literární priovodce metropoli v letech 1918-1938 [Avant-Garde Prague: A Literary Guide Through the Metropolis Between 1918 and 1939]. Praha: Academia, 2014.

Plakát Máj [Poster for 'Máj']. 1936. Divadelní oddělení Moravského zemského muzea, fond Lola Skrbková, složka Máj [Theatre Department of the Moravian Museum, Lola Skrbková collection, Máj folder].

POJAR, Miloš. 2001. Židovští účastníci Čapkových pátků a jejich osudy [Jewish members of the 'Pátečníci' Group and Their Life Stories]. In Pavel Janáček (ed.). Pátečníci a Karel Poláček [The 'Pátečníci' Group and Karel Poláček]. Boskovice: František Šalé - ALBERT, 2001: 59-65.

POKORNÝ, Jaroslav. 1946. Složky divadelniho výrazu [The Components of Theatre]. Praha: Ústav pro učebné pomůcky průmyslových a odborných škol, 1946.

Praha-Moskva 1 (1936): 1.

Praha-Moskva 2 (1937): 3.

Projev spisovatelů [Manifest of Literary Authors]. 1934. Lidové noviny 42 (28. 11. 1934): 599: 5.

RÁDL, Emanuel. 1935. Zur politischen Ideologie der Sudetendeutschen. Wien: K. Prager, 1935.

RŮT, Václav. 1964. Divadlo a rozhlas: Problémy rozhlasové hry [Theatre and Radio: The Issues of Radio Play]. Praha: Československý rozhlas: 1964. Disertace [dissertation] z roku 1936.

SAYER, Derek. 2013. Prague, Capital of the Twentieth Century: A surrealist History. Princeton: Princeton University Press, 2013.

SEIDLOVÁ-SLOTTYOVÁ, Ingeborg. 1936. Vliv národního socialismu na německý jazyk [Influence of the National Socialism on German Language]. Slovo a slovesnost 2 (1936): 1: 56-58. 
SEIFERT, Jaroslav. 1982. Vřechny krásy světa [All the Beauties of the World]. Praha: Československý spisovatel, 1982.

L. S. [SILBERSTEIN, Leopold]. 1935a. Linguistik und Phänomenologie. Prager Presse 15 (22. 11. 1935): 316: 8.

(L) [SILBERSTEIN, Leopold?, nebo LYER, Stanislav?]. 1935b. Die tschechische philosophische Terminologie der Gegenwart. Prager Presse 15 (5. 12. 1935): 329: 6.

(L. S.) [SILBERSTEIN, Leopold]. 1935c. Über reistische Sprachbetrachtung in ihrem Verhältnisse zur Logistik und Phänomenologie... Prager Presse 15 (19. 12. 1935): 343: 10.

SILBERSTEIN, Leopold. 1936. Vývoj rasových teorii [Development of Race Theories]. Praha: Orbis, 1936.

SLÁDEK, Ondřej. 2014. Jan Mukařovský and Theatre. Theatralia 17 (2014): 2: 122-136.

Slavistische Arbeitsgemeinschaft in Berlin. Prager Presse 12 (5. 5. 1932): 124: 8.

SRBOVÁ, Olga. 1941. Na přelomu slohů [At the Turn of Styles]. Život 17 (duben 1941): 2: 120-121.

Südslavischer Zirkel der Slavisten an der Deutschen Universität in Prag. 1931. Slavische Rundschau 3 (Januar 1931): 1: 63-64.

ŠMEJKALOVÁ, Martina. 2013. Havránek the didactician. In Bohumil Vykypěl (ed.). Bohuslav Havránek: Contribution to his life and work. Travaux linguistiques de Brno 10. München: LINCOM Europa, 2013: 74-105.

THIROUIN-DÉVERCHÈRE, Marie-Odile. 2002. Rudolf Pannwitz / Otokar Fischer / Pavel Eisner: Korespondence [Letters]. Praha: Památník národního písemnictví v Praze a Schiller-Nationalmuseum Deutsches Literaturarchiv v Marbachu, 2002.

TOMAN, Jindřich. 2011. Př́běh jednoho moderního projektu: Pražský lingvistický kroužek 1926-1948 [The Magic of Common Language]. Praha: Karolinum, 2011.

TRÄGER, Josef. 1945. Dvě prednášky z války o divadle [Two Lectures on the War and Theatre]. Praha: Umělecká beseda, 1945.

TRÁVNÍČEK, František. 1940. Divadelní mluva [Theatre Speech]. Program D 40 (9. 1. 1940): 3: 68-69.

VACHEK Josef. 1964. A Prague School Reader in Linguistics. Bloomington: Indiana University Press, 1964.

VACHEK, Josef. 1999. Prolegomena k dějinám pražské školy jazykovědné [Prolegomena to the History of the Prague Linguistic School]. Praha: H\&H, 1999.

VELTRUSKÝ, Jiří. 1945. Studio a divadelní seminář Karlovy university [Studio and Theatre Seminar at the Charles University]. In Jindřich Honzl (ed.). Studio Národniho divadla [Studio of the National Theatre]. Praha: Otto Girgal, 1945: 16-18.

Vier Vorträge über die zeitgenössische Kunst. 1935. Prager Presse 15 (12. 1. 1935): 11: 8.

VÉVODA, Rudolf. 1996. Muž, který byl nepohodlný aneb od agenta III. Internacionály k agentovi FBI [The Inconvenient Man or From the Agent of the Third International to the FBI Agent]. Středni Europa 64 (12) (listopad 1996): 9: 65-75 a 65 (12) (prosinec 1996): 10: 88-100.

VYKYPĚL, Bohumil. 2009. Empirical Functionalism and the Prague School. München: LINCOM, 2009.

VYKYPĚL, Bohumil. 2012. Vilém Mathesius - einige Bemerkungen zu seinem Leben und Werk. In Bohumil Vykypěl (ed.). Vilém Mathesius: Contributions to his life and work. München: LINCOM, 2012: 67-76. 
VYKYPĚL, Bohumil, 2013. Skizzen zur linguistischen Historiographie. München: LINCOM, 2013.

VYKYPĚLOVÁ, Tatána. 2005. Bratislavský lingvistický krúžok (Pressburger Linguistenkreis): die Grunddaten. Linguistica Brunensia 54 (2005): A53: 181-196. Dostupné z <https://digilib.phil. muni.cz/handle/11222.digilib/101727>.

Vyučování ruštině do středních škol! [Let Us Teach Russian at the Secondary Schools!] 1937. Praha-Moskva 2 (květen 1937): 3: 75-76.

WANIEKOVÁ, Štěpánka. 2014. Výstava Poesie 1932 [Exhibition 'Poetry', 1932]. Bakalářská práce, Filozofická fakulta, Masarykova univerzita [Bachelor thesis, Faculty of Arts, Masaryk University]. Brno: Masarykova univerzita, 2014. Dostupné z <http://is.muni.cz/th/384222/ff_b/Vystava_Poesie_1932_g3hse.pdf>.

WEINGART, Miloš. 1935. Zvukový film a řeč: čtyři základní kapitoly [Sound Film and Speech. Four Basic Chapters]. In Abeceda filmového scenaristy a herce. Soubor přednášek scenaristického kursu Filmového studia [The Basics of a Film Script Writer and Actor. Collection of Lectures Given in the Script Writing Course of the Film Studio]. Praha: Časopis Kino-Revue, 1935: 39-72.

WINNER, Thomas. 2015. The Czech Avant-Garde Literary Movement Between the Two World Wars. Ondřej Sládek, Michael Heim (edd.). New York: Peter Lang, 2015.

Zpráva o činnosti Pražského linguistického kroužku za desítiletí jeho trváni 1926-1936 [Report of the Activities of PLC in the decade Between 1926 and 1936]. 1936. Praha: Pražský linguistický kroužek, 1936.

Citované archiválie z Masarykova ústavu a Archivu AV ČR, fond Pražský lingvistický kroužek [Archival materials deposited in the Masaryk Institute and the Archive of the Academy of Sciences of the Czech Republic, The Prague Lingvistic Circle collection]

Kap. [chap.] IV. „Činnost“ [Activities], oddíl [part] $a$ „Pravidelná činnost“ [Regular activities], inv. č. [inv. no] 7, Zápisy výborových schưzi PLK [Reports from the PLC Comittee Meetings].

Kap. [chap.] IV. „Činnost“ [Activities], oddíl [part] $e$ „Korespondence se členy a spolupracovníky“ [Letters of members and collaborators], inv. č. [inv. no] 18, složka [folder] „K“, Korespondence PLK s Jaroslavem Kosem [Correspondence of PLC and Jaroslav Kos].

Kap. [chap.] IV. „Činnost“ [Activities], oddí1 [part] $f$ „Spolupráce s domácími i zahraničními institucemi“ [Collaboration with local and foreign institutions], inv. č. [inv. no] 19, složka [folder] „L“, Zpráva o činnosti Literárně historickéspolečnosti v Prazev VI. Správním roce 1940/41 [Report About the Activities of the Literary-Historic Society in Prague in the 4th year of its existence (1940/41)] .

Kap. [chap.] IV. „Činnost“ [Activities], oddíl [part] $f$ „Spolupráce s domácími i zahraničními institucemi“ [Collaboration with local and foreign institutions], inv. č. [inv. no] 19, složka [folder] „M“, Dopis Ministerstva školstvi a národni osvěty z 5. 2. 1930 [A Letter From the Ministry of Education and National Enlightenment, Feb 5, 1930].

Kap. [chap.] IV. „Činnost“ [Activities], oddíl [part] $f$ „Spolupráce s domácími i zahraničními institucemi“ [Collaboration with local and foreign institutions], inv. č. [inv. no] 19, složka [folder] „M“, Dopis Ministerstva školstvi a národni osvěty z 9. 10. 1931 [A Letter From the Ministry of Education and National Enlightenment, Oct 9, 1931]. 
Kap. [chap.] IV. „Činnost“ [Activities], oddíl [part] $f$ „Spolupráce s domácími i zahraničními institucemi“ [Collaboration with local and foreign institutions], inv. č. [inv. no] 19, složka [folder] „M“, Dopis Ministerstva zahraničnich věci Československé republiky Vilému Mathesiovi z 25. 10. 1929 [A Letter From the Ministry of Foreign Affairs of the Czechoslovakia to Vilém Mathesius, Oct 25, 1929].

Kap. [chap.] IV. „Činnost“ [Activities], oddíl [part] $f$ „Spolupráce s domácími i zahraničními institucemi“ [Collaboration with local and foreign institutions], inv. č. [inv. no] 19, složka [folder] „M“, Dopis Pražského lingvistického kroužku Ministerstvu školstvi a národni osvěty z 20. 9. 1934 [A Letter From the PLC to the Ministry of Education and National Enlightenment, Sep 20, 1934].

Kap. [chap.] IV. „Činnost“ [Activities], oddíl [part] $f$ „Spolupráce s domácími i zahraničními institucemi“ [Collaboration with local and foreign institutions], inv. č. [inv. no] 19, složka [folder] „M“, Návrh smlouvy o spolupráci mezi Pražským lingvistickým kroužkem a nakladatelstvím Melantrich, 28. 4. 1944 [A proposition of the contract concerning collaboration between the PLC and the Melantrich Publishing House, Apr 28, 1944]. 1944. In Dopis B. Trnky Melantrichu 24. 5. 1944 [A Letter From B. Trnka to Melantrich, May 24, 1944].

Kap. [chap.] IV. „Činnost“ [Activities], oddíl [part] $f$ „Spolupráce s domácími i zahraničními institucemi“ [Collaboration with local and foreign institutions], inv. č. [inv. no] 19, složka [folder] „N“, Dopis Národni rady badatelské Josefu Hrabákovi z 15. 1. 1941 [A Letter From the National Research Council to Josef Hrabák, Jan 15, 1941].

Kap. [chap.] IV. „Činnost“ [Activities], oddíl [part] $f$ „Spolupráce s domácími i zahraničními institucemi“ [Collaboration with local and foreign institutions], inv. č. [inv. no] 19, složka [folder] „N“, Dopis Národni rady badatelské Josefu Hrabákovi z 27. 1. 1941 [A Letter From the National Research Council to Josef Hrabák, Jan 27, 1941].

Kap. [chap.] IV. „Činnost“ [Activities], oddíl [part] $f$ „Spolupráce s domácími i zahraničními institucemi“ [Collaboration with local and foreign institutions], inv. č. [inv. no] 19, složka [folder] „R“, Dopis Rockefellerovy nadace B. Trnkovi z 25. 10. 1932 [A Letter From the Rockfeller Fund to B. Trnka, Oct 25, 1932].

Kap. [chap.] IV. „Činnost“ [Activities], oddíl [part] $f$ „Spolupráce s domácími i zahraničními institucemi“ [Collaboration with local and foreign institutions], inv. č. [inv. no] 19, složka [folder] „S“, Dopis B. Trnky Sdruženi pro divadelni tvorbu z. 5. 11. 1943 [A Letter from B. Trnka to the Association for Theatre Work, Nov 5, 1943].

Kap. [chap.] VI. „Knihovna, archiv“ [Library, archive], inv. č. [inv. no] 26, Kronika Pražského linguistického kroužku [Chronicle of the PLC], 1930-1938.

Kap. [chap.] VII. „Finance a hospodaření“ [Finances and management], inv. č. [inv. no] 27, Dopis Ministerstva školstvi a národni osvěty z 21. 3. 1936 [A Letter From the Ministry of Education and National Enlightenment, Mar 21, 1936]. 


\section{Summary}

\section{Scholarship as praxis: Prague linguistic circle, cultural activism and thought on theatre}

Structural approach to theatre was developed in the late 1930s and during the WW2 in frame of Prague Circle ("PLC") as a result of an activist approach to scholarship and close collaboration between theatremakers and scholars. Although the connection between avant-garde aesthetic of 1930s and structuralist writing on theatre has been already described, there are more important relations beyond that generally acknowledged frame. Seminal structuralist essays on theatre were often written as polemics that were addressed, besides regular readers, to the opponents of PLC members. They were also written in the already changed cultural context, where the previous avant-garde model was the object of reflection and overcoming. Furthermore, this approach was driven by the need to explain Avant-Garde theatre to general public by terminology of modern scholarship. The so called Prague theatre structuralism could be therefore seen as a paradigm of scholarship that formulates its theories with respect to science popularisation as well as an attack against other "actors" in the field of theatre studies. The author focuses on the practical and organisational aspect of the PLC. Different modes of collective action in the public space as well as material conditions of existence and financial support are described. Attention is also paid to national and political (leftist) affiliation of the members of the Circle. From this perspective the PLC approach to theatre is analyzed as set of action rather than set o text and ideas.

\section{Klíčová slova}

Pražský lingvistický kroužek, divadelní teorie, divadelní praxe, divadelní věda, popularizace, Jan Mukařovský, Jindřich Honzl, Jiří Veltruský, Emil František Burian, druhá světová válka

\section{Keywords}

Prague Linguistic Circle, theatre theory, theatre praxis, theatre scholarship, popularisation, Jan Mukařovský, Jindřich Honzl, Jiří Veltruský, Emil František Burian, World War II.

DOI: $10.5817 /$ TY2016-1-1

Martin Bernátek (bernatek@mail.muni.cz) se zabývá vztahem divadla, architektury a médií a dějinami divadelních studií zejména v první polovině 20. století. Studoval dějiny divadla a kultury a teorii interaktivních médií na Masarykově univerzitě, Laponské univerzitě a Varšavské univerzitě. Od roku 2013 je odborným neakademickým pracovníkem Katedry divadelních studií MU (Brno, Česká republika). Byl spolueditorem antologie Manifesty pohyblivého obrazu: barevná hudba (2010), sestavil Bibliografii článků o Pražském lingvistickém kroužku v německojazyčném tisku v ČSR (2015).

Martin Bernátek (bernatek@mail.muni.cz) is a researcher in the field of theatre architecture, theatre and media relations, and theatre scholarship, particularly with regard to the first half of 
the $20^{\text {th }}$ century. He studied history of performance and culture, and interactive media theory at the Masaryk University, the University of Lapland, and the University of Warsaw. Since 2013 he has a non-academic position at the Department of Theatre Studies, Masaryk University (Brno, Czech Republic). He co-edited the anthology Manifests of Moving Image: Color Music (2010) and published the Bibliography of Prague Linguistic Circle's reception in German Language Press in the Czechoslovak Republic (2015). 